\title{
2 CONTESTED HERITAGE: THE "CUL-TOURISTIC" TURN IN THE CELEBRATION OF IRREECHA RITUAL IN ETHIOPIA
}

\section{Serawit Bekele Debele ${ }^{1}$}

\section{INTRODUCTION}

Until the 1974 outbreak of the revolution that led to the end of the imperial regime, religious freedom in Ethiopia was not enjoyed by all. For centuries since its introduction, the Ethiopian Orthodox Christianity was recognised as a state religion with a significant socio-political, cultural as well as economic influence. The same church also had the privilege of defining national identity to the extent that, until recently, Ethiopia was depicted as an "island of Christianity". Other religions like Islam, Evangelical and Catholic Christianity as well as indigenous religions were marginalised. The case with the indigenous religions was even more problematic, because they were not only marginalised, but also made objects of criticism as backward practices. Thus, the Ethiopian Orthodox Church was the only institution that was strictly regarded as a national heritage with which many proudly identify. ${ }^{2}$ Nevertheless, with the emergence of a socialist-oriented regime in 1974, this assumed a different form as the government introduced certain reforms that recognised all religions and also declared secularism as a governing principle.

Since then, there has been a relative freedom enjoyed by all religions, although repression on religious groups and institutions was more often than not characteristic of the military regime. ${ }^{3}$ After seventeen years of civil war, an ethnic coalition called Ethiopian People's Democratic Revolutionary Front (EPRDF)

1 Serawit Bekele Debele is a Fritz Thyssen Stiftung postdoctoral fellow at the department of religious studies: University of Bayreuth, Germany.

2 For instance, Islam was introduced to Ethiopia in the seventh century, thus having a history as old as that of Ethiopian Orthodox Christianity. Until very recently, its status as a national historical heritage that has shaped the country's past was less acknowledged, although of late there is a re-emergence of Islam in the public debate about what makes a national identity in Ethiopia, owing to the vibrant scholarship that focuses on the religion.

3 The military regime introduced certain reforms that were greatly commended by the public. For instance, Islamic holidays like Ramadan were accepted as public holidays like Easter, Christmas and other Christian celebrations. However, the regime was also known for repressing certain religious institutions like Evangelical churches on allegations of relationships they were assumed to have with political organisations. The Mekane Yesus Evangelical church was one such victim due to its alleged association with the Oromo Liberation Front. Thus, regardless of the reforms, the regime was rather ambivalent in the way it related to religious institutions, making the insertion of secularism a superficial government intervention to demarcate the separation of religion and politics. 


\section{Religion, Pluralism and Heritage in Ethiopia}

took power in 1991. The new regime introduced a constitution in 1995 in which religious freedom was granted. Ethnic federalism also became the organising principle of the federal state of Ethiopia. The era of ethnic federalism in post1991 Ethiopia provided a legal framework that promoted and celebrated ethnic, religious and cultural diversity. Owing to this, identity politics took centre stage; which in turn necessitated the revitalisation of ethno-nationalist sentiments that found expression in most of the previously marginalised and now reviving cultural and religious practices.

Irreecha, the annual ritual of thanksgiving, is a religious festival that gained prominence and visibility following the change of regime in 1991. There are two major seasonal rituals. The first, known as Irreecha Tulu (meaning hilltop), takes place to pray for rain, and it is held just before the rainy season commences. People gather at the top of a sacred mountain to plead with Waaqa (the creator) to give them enough rain for the harvest and also to protect them, their family members, the cattle and everything else that he created. The second one is what is called Irreecha Melka (lake). This is held to express gratitude to Waaqa, who has given the people and the cattle enough rain and also transited them from the foggy and rainy to the sunny and beautiful spring. Irreecha Tulu and Melka may take place at different sacred sites. In this chapter, I am focusing on the major Irreecha Melka that is held as an opening before all others take place. It takes place on a Sunday at the end of September or first week of October at Hora Arsedi, a sacred lake located in the Bishoftu city of Oromia Regional State. It is an important event among the Oromo ${ }^{4}$ and other ethnic groups, as it is a season of change from the dark to the sunlight. It is a transition to the season of harvest, a time when the rivers and streams settle and communication among relatives and friends resumes. As a way of appreciating Waaqa's (sky God) kindness for his protection and provision, it is held to extend appreciation and also pray for further prosperity, health and success throughout the year. It is a time to celebrate nature. On this occasion, participants carry freshly cut grass and trek to the lake, where they dip the grass inside the holy water and sprinkle it on themselves, because the water is believed to have a healing and cleansing effect. ${ }^{5}$

4 The Oromo are the largest ethnic group in Ethiopia. They live in the Oromia Regional State of the Federal Democratic Republic of Ethiopia. In the current political setup, they are represented by the Oromo People's Democratic Organisation (OPDO), a member party to the ethnic coalition that currently rules the country called Ethiopian People's Revolutionary Democratic Front (EPRDF). They are followers of Waqqeffana, Islam and Christianity (of various denominations). Since change of regime in 1991, there has been an active cultural and religious revival and as will be dealt with in my forthcoming book, the revival has political overtone, which is also what makes Irreecha an interesting entry point to understand the complex and dynamic interaction of Oromo national identity, cultural revival, articulation of political demands and aspirations.

5 While conducting my fieldwork in Bishoftu, I have been told by many participants that they come to fetch the holy water on ordinary days, not just on the main day, to keep it at home to fend off bad spirits and any other sources of ailment 
Irreecha brings together thousands of participants from all religious (some of which are Ethiopian Orthodox Christians, Pentecostals, Evangelicals, Catholics, Muslims, followers of the Oromo religion called Waqqeffana) and ethnic backgrounds (for example Amhara, Tigre, Gurage), although the Oromo are predominant. The ritual is also characterised by various colourful events like votive offerings (gifts offered when someone's acknowledges that her or his prayers are answered), spirit possession, invocation songs and ululations, trance, coffee ceremonies, libation and so on. In addition to such ritual performances, it is also commonplace to observe modern music bands performing on a stage built by the city municipality. Folk songs by a group of Oromo females and males are also a noticeable feature of the ritual celebration. Given its ever increasing popularity, its socio-political and economic significance, political dignitaries, including the regional state's president, attend the ritual and address the public through their speeches. Of late, it has also become a site of curiosity for both local and foreign tourists as a result of which millions flock to the sacred lake on the day of the celebration. Since 2007, the Oromia Regional State's Culture and Tourism Bureau has involved itself as a custodian and organiser of the ritual. Although the civil society association called Mecha and Tulema Association was responsible in making Irreecha popular at in the 1990s and early 2000s, the role of the regional state's tourism bureau is paramount in elevating Irreecha into a tourist attraction that is no longer confined to the local celebrants. ${ }^{6}$

This active government involvement through the bureau has led to the gradual shift in the articulation of Irreecha from a "religious ritual" to a "cultural festivity". Under the auspices of the bureau, Irreecha is reinvented as an intangible cultural heritage that mobilises the Oromo across religious

and affliction. Many also shared testimonies in which they said that they have witnessed some healing being conducted. The most common problem is related to child bearing. Barren women come to the lake and immerse themselves with the water in the hope that they get children. For some, so I was told, it worked and the next year they return with their offerings to extend their gratefulness.

6 A more detailed account of the ritual is available in my forthcoming book titled Managing Irreecha: Religion and Politics in post-1991 Ethiopia. The main finding of my research is that Irreecha is appropriated by political groups, both the state and its opponents, as a space of self-presentation and/or airing resistance against the current political goings on in the country. It is a site that is managed by political actors for the production of governable subjects. It is also where political engagement by the people is actively taken to manifest ambivalent political practices which fall in the spectrum of supporting and resisting the regime. This interplay of celebrating national identity and political engagement reached its climax in the celebration of 2 October 2016. During this time, the nationwide \#Oromoprotest that has been going on in the country since 2014 found expression at Hora Arsedi. The youth seized the opportunity to unanimously express their protest and resistance against the continued government crackdown including other fundamental political demands. This eventually culminated with the death of hundreds following the firing of teargas in an attempt to contain the protesting youth. This incident is both a reflection of past state-society relation and will have significant ramifications for the country's political developments in the years to come. 


\section{Religion, Pluralism and Heritage in Ethiopia}

backgrounds to celebrate their collective national identity. This reinvention is predicated on the exclusion of spirit mediumship and practices to that effect. Whereas reverence to Waaqa and the benevolent spirits is central to Irreecha, government officials and some educated elites assert that the practice of revering such entities should not be considered as a constituting element. Particularly, spirit mediumship as it happens at Hora Arsedi is depicted as a backward practice by some and the worship of evil spirits by others.

Such association of spirit mediumship with backwardness and evilness is readily accepted by officials and experts in the tourism bureau, which shows a will to involve itself into the process of redefining the ritual. By redefining Irreecha as a cultural expression, the officials dissociate the ritual from the spiritual practices. This is accompanied by what I call a "cul-touristic"7 turn, meaning a process of commodification and commercialisation of the ritual in a manner that makes it, as well as the city of Bishoftu, a tourist attraction, not only to local consumers but also to foreigners. ${ }^{8}$ This brings in the economic dimension of appropriating and editing the ritual by the culture and tourism bureau. The "cul-touristic" turn is important, as it makes Irreecha marketable to a wide range of Oromo participants who do not necessarily subscribe to everything the ritual delivers. For instance, Protestant and Evangelical Christians and some conservative Muslim and Ethiopian Orthodox Christians are ardent critics and opponents of such practices like possession trance. ${ }^{9}$ Some even reject Irreecha in its entirety. Emphasising on the cultural and touristic aspects of Irreecha makes it accessible to this group of critics, because it is articulated in a manner that does not contradict with their religious convictions. However, the redefinition is not simply accepted by all. It is contested and challenged by those who passionately defend the ritual's spirituality.

7 I coined the term "cul-touristic" in order to better capture the involvement of the Oromia Regional State's Culture and Tourism Bureau and the change and continuity experienced in the articulation and celebration of the thanksgiving ritual. The term is driven from culture and tourism. It is used to show the gradual expansion of Irreecha into a cultural event and narrowing scope of the spiritual aspect owing to the involvement of the bureau in addition to the active promotion of the ritual as a tourist attraction.

8 Such representation of indigenous religious practices like spirit mediumship and possession cults has a historical foundation, since the Ethiopian Orthodox Church, Islam and Evangelical Christianity uprooted local practices and converted people who were incorporated within the Christian empire. The success of Christianity's expansion partly depended on denigrating such local practices as things of evilness that people have to break away from. While this is the historical basis of their denigration as backward and evil, the recent outreach by the Evangelcals and Pentecostals in the country has made the mediums' marginalisation even higher than before. There seems to be an implicit alliance between these religious groups and some officials in the bureau.

9 For more on the religious demography of Ethiopia, see online at: http://www.globalreligiousfutures.org/countries/ethiopia\#/?affiliations_religion_ $\mathrm{id}=0$ \&affiliations_year=2010\&region_name=All\%20Countries\&restrictions_year=2014 
As a result, two antagonistic groups are at loggerheads. On one hand, there are those who advocate Irreecha as a purely cultural event, while on the other there are those who contest this as a "despiritualisation" of the ritual which otherwise revolves around Waaqa and the spirits. These two groups have actively contested - at times even violently - the shift in meaning and significance of Irreecha. The role of the culture and tourism bureau in establishing the shift towards what I call the "cul-touristic" tone is significant. Given that the proponents of possession trance are subordinated both historically and currently and also because they are a minority, suppressing their stories is much easier compared to the risk the government takes of losing a larger number of Oromo participants who ultimately reject the mediumship and possession trance at Hora Arsedi. Drawing on ethnographic research conducted over the last five years in Oromia, this chapter reflects on the role of "secular" institutions in the contestation, reconstruction and/or transformation of intangible heritages.

\section{HERITAGE AS PROCESS AND DISCOURSE}

Laurajane Smith, a professor of heritage studies, ${ }^{10}$ conceptualises heritage in a manner that makes it break away from "thing-ness" with an intact and timeless essence by articulating it as a discourse, process, work and performance. She defines it as a socio-cultural process of connecting to an object and a practice that is located in the experience of people in relation to certain performances (like rituals) or objects (like sites). Emphasising its performative aspect, Smith combines heritage with doing something and states that it is a work of "being in place, renewing memories and associations, sharing experiences with kinswomen to cement present and future social and familial relationships. Heritage wasn't only about the past - though it was that - it also wasn't just about material things - though it was that, too - heritage was a process of engagement, an act of communication and an act of making meaning in and for the present." ${ }^{11}$ As such, it is a political process that involves diverse interest groups and bound to a set of power relations. Smith further establishes that heritage as a process is mostly created and recreated in the interest of the powerful groups, which have the means to legitimise or delegitimise what is regarded as heritage. Its creation becomes possible in response to various nationalist and political agendas, making it "a dynamic process which involves competition over whose version of the past, [the present and the future]" to preserve and designate as heritage. ${ }^{12}$ This might result in the subordination of some discourses propagated by people who have less or no power compared to the authorities who demarcate the boundaries and limits of what heritage entails who in turn contest the imposed version of heritage.

10 Smith L. 2006. Uses of Heritage. New York: Routledge.

11 Smith, Uses of Heritage, 1.

12 Smith, Uses of Heritage, 8. 


\section{Religion, Pluralism and Heritage in Ethiopia}

To capture such a complex and dynamic process and practice of heritage formation, Smith developed the notion of "authorised heritage discourse", which rests on the argument that heritage is a discourse in its own right. Smith states that, "authorised heritage discourse" is a notion that encapsulates such a political and power-imbued process of de/nominating heritages. ${ }^{13}$ Arguing along this line, archaeologist Rodney Harrison writes that authorised heritage discourse "is a set of ideas that works to normalise a range of assumptions about the nature and meaning of heritage and to privilege particular practices, especially those of heritage professionals and the state. Conversely, the 'authorised heritage discourse' can also be seen to exclude a whole range of popular ideas and practices relating to heritage" ${ }^{14}$ It is also, I argue, as much concerned with challenging the powerful agents, namely experts and professionals who are behind what is designated as heritage and whose say in delineating heritage is regarded as valid. It is in this conceptual context that I look at what I call the "cul-touristic" turn in the articulation of Irreecha and the role authorised experts from the regional state's bureau play in removing certain elements as irrelevant while recreating others as authentic expressions of ethnic identity.

\section{AUTHORISING IRREECHA AS CUL-TOURISTIC FESTIVAL AND THE ENSUING DEBATES}

As it stands now, Irreecha has secured nationwide popularity not only in the Oromia region, but also in the whole country, as well as in the diaspora. It has become a point of curiosity, and questions regarding whether it is a cultural or religious celebration are increasingly debated. One of the multiple manifestations of the spirituality of the ritual is the spirit possession and trance that take place under the sacred tree, following the process of people dipping the freshly cut grass into the sacred lake and spreading it on their bodies. The possession and trance, accompanying coffee ceremony and votive offering are points of contention for many. While there are people who clearly understand it to have a religious intonation, others utterly discard the notion of Irreecha as religious and hence reject the aforementioned rituals. The bureau has a stance towards spirit mediums and the rituals that go on under the tree. They are regarded as grotesque which makes them unwanted additions to the "pure" Oromo cultural and religious tradition. They are also considered as alien practices that are not supposed to be viewed as part of the celebration. If, according to the bureau's statements, Irreecha accommodates such ritual performances, then instead of attracting, it repels a significant number of Oromo and loses its currency as a unifying celebration. It becomes confined to a few who regard it as a gathering to appease the divine. In this case, the place also

13 Smith, Uses of Heritage.

14 Harrison R. 2010. "What is Heritage?", in Harrison R (ed). Understanding the Politics of Heritage. Manchester: Manchester University Press, 5-42, 27. 
becomes nothing more than a pilgrimage site that caters to the spiritual needs of only a certain group of people who subscribe to practices of mediumship at Hora Arsedi. Particularly, the main organiser of the ritual celebration, the regional state's bureau of culture and tourism, is of the view that Irreecha should be understood as a "neutral ground" that is conveniently accessible to all Oromo regardless of their religious convictions. Framing it as a cultural festivity that is removed from the spirituality some attribute to it makes the celebration open to a wide range of attendants. Portraying it as a cultural festival is predicated on the assumption that, compared to religion, culture is viewed as less compelling and to take part in such a colourful festival like Irreecha, one does not have to accept the spiritual aspect of the ritual as its integral part. Such a privileged and essentialised narrative is justified because it presents Irreecha in connection with ethnic identity and as a symbolic event that cements the Oromo across religious and cultural differences. In this way, Irreecha is linked to the broader notion of imagining the Oromo as a homogenous nation.

For instance, the commissioner of the regional state's bureau is clear in his assertion that it is not for the bureau to accommodate the spiritual aspect of the celebration, even more so because it is a secular institution whose task is not to promote religions. Promoting Irreecha as a cultural festivity serves as a pragmatic "strategy" because it brings together a religiously diverse but "ethnically homogenous" group of people. In the words of Oromo official Mohamed Jilo, "since Irreecha is very much connected with the Oromo identity; we are using Irreecha as a platform to create unity among the Oromo."15 Along this line, an expert in the bureau by the name Alemu Serbesa, who is an anthropologist and a historian, argues that permitting spirit mediums and their practices during the celebration of Irreecha defeats the objective of appropriating it as an authentic heritage of the Oromo who have diverse confessions since not every participant subscribes to spirit possession activities. Most importantly, the mediums' act is seen rather as a source of "aesthetic deformation", to use Serbesa's own expression. For him, this deformation, unless removed, keeps at bay a large number of participants by disfiguring an otherwise pleasant ethno-cultural event. ${ }^{16}$ Using such narratives, the authorities and experts in the bureau eschew accommodation of practices that are not acceptable to the elite. Moreover, in the service of making it attractive by erasing the spiritual dimensions from Irreecha and thereby secularising it, the government justifies its claims of distancing itself from religious affairs. This is so because if Irreecha's secularity is highlighted by the bureau, then the government could not be

15 Interview with Mohamed Jilo, Addis Ababa, Ethiopia, 24 October 2013.

16 Interview with Alemu Serbesa, Addis Ababa, Ethiopia, 22 November 2013. It is also important to mention that the office is organising certain movements to reform Irreecha in line with the "unifying" culture oriented definition the office ascribed to it. For instance, until September 2012, mediums used to gather on the eve of Irreecha by the lakeside to perform an all night long ritual of pleading with Waaqa and the spirits. Since 2012, however, they have been banned by the police from spending the night at Hora Arsedi. 


\section{Religion, Pluralism and Heritage in Ethiopia}

blamed for violating its own constitutional provisions on secularism which dictate state non-intervention. To achieve this, the experts and authorities are invested with the power to define and legitimise the "cul-touristic" narrative which makes the ritual both marketable as a tourist attraction and accessible to non-believing Oromo participants. Needless to say, the secularising narrative privileges and expands only a certain strand of the ritual as its normal and natural definition. Hence, in addition to socio-economic mobilisation, there is a clear political motive and benefit to promoting it as a cultural heritage.

Smith rightly asserts that such authorised narratives, like the one propagated by the bureau as pronounced by professionals, privilege "expert values and knowledge about the past and its material manifestations, and dominates and regulates professional heritage practices".${ }^{17}$ The experts at the tourism office resort to certain discursive universes to define Irreecha as a cultural heritage and delegitimise other meanings attributed to the ritual by describing them as sources of "aesthetic deformation". Such expressions are readily accepted by many, because they are coming from experts, who seem to be more trusted than others given that they have the professional input to normatively delimit what is right and wrong. As it appears, Irreecha and the discourse regarding its meaning are perpetuated by experts, whose professional intervention in the construction of its new meaning is thereby endorsed.

Such experts focus on promoting what they believe is "normal" and aesthetically pleasing to certain sections of the elite and they seem to have the support of the bureau to perpetuate the discourses. This tendency of appropriating Irreecha as a "cul-touristic" event that mobilises the Oromo across religious backgrounds and also attracts tourists from elsewhere, entails a reinterpretation, and leads to the emergence of conflicting views on whether Irreecha is a religious ritual or a cultural event. However, the bureau's authorities, as well as its experts, have the political and symbolic capital to enforce and promote the interpretation that presents Irreecha as a "cul-touristic" festival. Promoting the ritual as an authentic Oromo culture presupposes the removal of some practices, which are labelled as additives that are not fitting with the tradition. Removing certain practices in turn narrows Irreecha's wider and complex meaning. This development is a clear indication that heritage is a discourse in the sense that it goes beyond the use of language for communication. It is a practice informed by power relations in which ideologies, knowledge and meaning are embedded. In such a hegemonic context of knowledge production, dissenting or alternative voices regarding heritage discourse are not permitted to flourish

\section{CONTESTING THE "CUL-TOURISTIC" TURN}

Heritage is about the construction, negotiation, expression and contestation of multiple identities and socio-cultural as well as religious values. Despite this,

17 Smith, Uses of Heritage, 4. 
widening the cultural aspect of Irreecha as an Oromo heritage has understated these multiple meanings and interpretations. By inflating and authorising the cultural aspect of the ritual, the authorised experts have reduced it to something that has a single meaning with which all participants should identify. This imposes on participants a uniform take on and relationship to the ritual. The experience that emerges from being there is ultimately dictated by the experts, leading to the contestation of Irreecha as an intangible cultural heritage. The contestation emerges out of the fact that heritage, as highlighted by Smith, ${ }^{18}$ is as much a point of promoting consensus about the past as challenging the status quo imposed presently by the hegemonic authorities.

For instance, articulating Irreecha in culturalist manner has resulted in the marginalisation of the spirit mediums of which the Oromo are a significant constituency. On the other hand, this hegemonic categorisation of sites, cultural and/or religious traditions as heritage changes their relationship to the local people. It becomes set apart, foreign, special and far from the everyday because of its redefinition as a heritage that either contradicts the local perception of the practice and its objectives or does not respond to the needs of the locals. In the case of Irreecha at Hora Arsedi, this authorised reformulation of Irreecha as a cultural semiotics is knitted with the tensions that emerge from the religious tones of the ritual and are brought to the fore by mediums and their followers.

While the culture and tourism bureau is attempting to widen up the cultural semiotics, those who define and relate to Irreecha in strictly spiritual terms are not passively receiving the imposed definition of the ritual that downplays its spiritual tone. For instance, spirit mediums and their followers assert themselves as patrons whose relationship to and experience with the event need to be taken as seriously as the one proposed by the authorised experts who emphasise the elitist notion of Irreecha as a symbol of ethnic identity. In their assertions, they stress that what makes the ritual what it is, including its increasing popularity, is the spiritual force that is attributed to the sacred site and the event. ${ }^{19}$ They also make reference to the provision of the Constitution of the Federal Democratic of Ethiopia, which equally grants religious freedom at both individual and associational levels. ${ }^{20}$ Based on the constitution, they accuse the authorities of intervening in what should not be their concern. By making reference to the constitutional provision of state non-intervention in religious affairs, spirit mediums and their constituencies challenge the experts of the bureau for imposing their view on the religious event using their power while it is outright wrong to do so as far as the constitution goes. In the mediums' view, this obviously contradicts the constitution and showcases the gap in the implementation of the legal provisions on religious freedom both as an individual and in association.

18 Smith, Uses of Heritage.

19 Interview with Kuma Ide'a, Dukem, Ethiopia, 16 February 2013.

20 Constitution of the Federal Democratic Republic of Ethiopia, art 11. 


\section{CONCLUSION}

By flattening out the diversity into singularity, the authorities have attempted to regulate the definition of Irreecha as a cultural heritage that has less or even nothing to do with religion. This action has led to the tension, since a significant number of people challenge the value the authorities have ascribed to it. This tension is a reflection of alterations in the popular understanding of cultural and religious values and also the resistance against manifest dictatorial approaches in delimiting what is and is not heritage. The redefinition of Irreecha by the bureau as a "cul-touristic" event that does not necessarily endorse and reflect the spiritual aspect mirrors also the fact that heritages are instrumentalised by regimes in the contested arena of identity formation and expression. It also shows that the reaction by the subaltern to such an imposition is another sign of the agentive role actors play to challenge and even reject imposed values that do not necessarily reflect their view of heritage.

Clearly, the way Irreecha is reframed as an intangible heritage by the bureau feeds on and responds to the demands of the privileged few. This way of approaching Irreecha by the experts and authorities does not account for diverse participants' diverse senses of being there and taking part in the ritual. This is a clear indication of the role of secular institutions in the reconstruction of certain events in the interest of an ideology which is geared towards managing the public into a homogenised set of categories in the name of "celebrating ethnic identity unanimously". This, however, is not to imply that there is absolute uniformity in the way the authorised narrative is received even within the bureau. There are some experts and ordinary participants who, along with spirit mediums, contest this narrative that makes the spiritual significance of the ritual irrelevant. These sections of Irreecha participants lament the ritual's increasing commodification and also that it is losing its spiritual might. Some even go to the extent that at some point Waaqa and the spirits might withdraw from supporting the Oromo. Thus, the "cul-touristic" turn is not lightly taken by those who fear detrimental consequences that stem from disregard to the spirits Waaqa assigned.

Irreecha is a multifaceted and complex ritual that takes place in a site which is imbued with different meanings that are informed by experiences of participants from different walks of life. It is where various religio-cultural works and multiple identities are performed and expressed. As much as a site for leisure activities of touristic interest, it is an event which is connected to spiritual convictions of certain groups of people. It caters to the aesthetic pleasure and identity affirmation of an elite class as much as it attends to the religious needs of the local celebrants of the ritual. As such, one could assert that Irreecha is an event in which more complex and nuanced socio-cultural as well as religious processes and formations are at work. However, as far as the bureau is concerned, Irreecha is a means of celebrating a seemingly secularised Oromo national identity; it is a site of celebrating Oromo-ness. Thus, there is no 
interest in endorsing the multiplicity of perspectives that emerge from different positions. Through the culture and tourism bureau of the Oromia region, the state's constitution of the ritual fixes it within the confines of the cultural and touristic interests which lead to the emergence of one dimensional and static meaning. It simply becomes an elitist orthopraxy that is cut off from other developments within various perspectives.

The bureau, relying on the power vested in it, is producing social, political and religious norms by inventing a certain narrative and undermining other alternatives as nonexistent or wrong. It downplays diversity by censoring and controlling narratives, while making us believe that there is singularity of meaning which all have accepted. There is an apparent lack of room to take into account multiple perspectives coming from different subject positions towards Irreecha as heritage. This shift in discourses and narratives has ramifications for the manner in which heritages are used to express identities and belongingness. Instead of allowing multiplicity of meaning through which various identities are constructed and expressed, heritage becomes confined to the meanings ascribed to it by the dominant groups. Such confinement of heritage to the powerful few makes it lose its connectivity with broader section of participants. The crucial part of this problem is also related to the question of preservation and sustainability of a given heritage. If people lose interest in it because it does not represent them and if they do not identify with it, they care less to preserve it and pass it on to the next generation.

Irreecha is appropriated for claiming an Oromo cultural space in the wider politico-cultural landscape in Ethiopia. Its reformulation in this manner is attributed to ethnic federalism that encourages the spectrum of ethnicity as a substantive aspect of national identity. It is under this landscape of competing for cultural spaces and representation in the wider national context that Irreecha became appealing for appropriation as an affirmation of Oromo national identity by expanding on its cultural traits. This "cul-touristic" turn expands the ritual's meaning in the national politico-cultural landscape by giving the Oromo a source of self-assertion and representation. However, this discourse and practice operate at the risk of narrowing down the pluralities of experiences, meaning-making and relationships observed with regards to Irreecha. While such an appropriation of Irreecha empowers the Oromo as a great nation with a proud culture that can assert itself in the national arena, it is disempowering for those whose view of Irreecha is linked to its spirituality. Thus, Irreecha's instrumentalisation as a secular rubric of national representation is made possible at the risk of the subalternisation of indigenous religious traditions as it involves the modification and inflation of the ritual to make it befitting to a national culture. This in turn manifests the tension and contradictions between constitutional implementation of religious freedom versus prioritisation of identity politics which comes from the state's commitment to ethnic federalism. 


\section{Religion, Pluralism and Heritage in Ethiopia}

Finally, linking Irreecha to the tourism office and redefining it in cultural terms has multiple implications in broadening the understanding of religion in relation to politics. The current state is praised for the religious reforms it introduced, championing secularism by clearly stating that the state shall not intervene in religious matters and religions shall not interfere in state related affairs. However, the Ethiopian state has not completely broken with the past in the way it is implementing secularism as a governing principle. While statereligion interplay is the continuation of a legacy from the past, the contemporary Ethiopian state has brought more religions to the fore - this is the new development the change of regime introduced. However, the regime is afraid of religion and sees it as a danger to state, despite the enormous power wielded by the state. In response, the state meddles in religious affairs in manifold ways. Where necessary, it defines by setting the parameters and boundaries to decide what amounts to religious and at which point something becomes cultural. The discourses revolving around Irreecha as a national heritage provide evidence to show that the link between state and religion is much more complex and, in fact, opposed to the dictates of constitutional provisions on secularism. 